\title{
HUMAN HERPESVIRUS-7 AS A CAUSE OF EXANTHEMATOUS ILNESSES IN BELÉM, PARÁ, BRAZIL
}

\author{
Ronaldo B. FREITAS, Maria R. FREITAS, Consuelo S. OLIVEIRA \& Alexandre C. LINHARES
}

\begin{abstract}
SUMMARY
We screened sera from 370 patients suffering from exanthematous illnesses in Belém, North Brazil, for the presence of human herpesvirus-7 (HHV-7) IgM and IgG antibodies. Samples were obtained from January 1996 to December 2002 and were processed by a HHV-7-specific indirect immunofluorescence assay (IFA). HHV-7-specific IgM and/or IgG antibodies were found in 190 (51.4\%) of these patients, with similar prevalence rates (IgM+ and IgG+ subgroups taken together) for female and male subjects: $52.5 \%$ and $50.3 \%$, respectively. Serological status as defined by IgG was identified in 135 (36.5\%) patients. In 55 (14.9\%) of the patients HHV$7 \mathrm{IgM}$ antibodies were detected. HHV-7 IgM- and- IgG antibody rates were similar ( $\mathrm{p}>0.05)$ when male and female subjects are compared: $14.4 \%$ versus $15.3 \%$ and $38.1 \%$ versus $35.0 \%$, respectively. Statistically significant difference $(p=0.003)$ was noted when HHV-7-IgM-positive female and male patients aged 5-8 months are compared. Prevalence rates ranging from 4.6\% (female, 5-8 months of age) to $93.3 \%$ (female, > 10 years of age) and $12.2 \%$ (male, 5-8 months) to $80.0 \%$ (male, 8 -10 years of age) were noted in the IgG- positive subgroups. A subgroup $(n=131)$ of patients with IgM or IgG HHV-7 antibodies were examined for the presence of DNA using a polymerase chain reaction/nested PCR. Recent/active HHV-7 infection occurred at a rate of 11.0\% (6/55) among patients whose samples presented IgM+ specific antibodies. In a subgroup $(\mathrm{n}=76)$ of patients with high HHV-7-IgG antibody levels (titre $>1: 160$ ) DNA could not be detected in sera examined by PCR/nested PCR. Of the six recent/active infections, four subjects with less than 1 year and two with 3 and 6 years of age, presented typical exanthem subitum (E.S), as defined by higher fever $\left(>38.0^{\circ} \mathrm{C}\right.$ ) with duration of 24 to 72 hours, followed by a maculopapular skin rash. Our results underscore the need for searching HHV-7 infection in patients with exanthematous diseases, particularly those presenting with typical E.S. HHV-7 appears therefore to emerge as a newly recognized pathogen of exanthem in our region.
\end{abstract}

KEYWORDS: Human herpesvirus-7 infection; Exanthematous illness.

\section{INTRODUCTION}

Human herpesvirus-7 was first isolated by FRENKEL et al..$^{15}$ from activated $\mathrm{CD}^{+}$peripheral blood $\mathrm{T}$ cells of a healthy individual in $1990^{2,20,23}$. It is currently known to belong to the $\beta$ - herpesvirinae subfamily ${ }^{2,24}$.

HHV-7 is ubiquitous and primary infection occurs mainly during infancy between the ages of 2 to 5 years ${ }^{3,6,39}$, therefore later than that of HHV $-6^{16}$. The exanthema subitum (E.S) is the commonest clinical presentation of the HHV-7 infection in infancy and childhood d, $^{1,17,31,34}$. Serological evidence for primary HHV-7 infection has been obtained from adult patients with pityriasis rosea ${ }^{14}$, aseptic meningitis ${ }^{24,42}$ and chronic fatigue syndrome ${ }^{13}$. In addition to this, neurological disease in children with E.S has been evidenced through the occurrence of febrile convulsions and acute hemiplegia ${ }^{23,24,25,33,34,35}$. Childhood HHV-7 recurrent fever has also been reported ${ }^{1}$. Recently, HHV-7 has been isolated from saliva of healthy adults, indicating that salivary glands are a likely site of $\mathrm{HHV}-7$ replication ${ }^{38}$.
Studies on the seroprevalence for HHV-7 infection conducted in USA yielded rates that exceed $85.0 \%{ }^{11}$. In $\mathrm{Japan}^{41}$, seropositivity rates in children aged 1 to 4 and 7 to 8 years were $45.0 \%$ and $40.0 \%$, respectively. Also in Japan, primary HHV-7 infection was estimated to occur in $10.2 \%$ of patients with clinically diagnosed E.S, as reported by HIDAKA et $a l .{ }^{17}$. In a study conducted by BLACK et $a l .{ }^{4}$ among Brazilian children clinically diagnosed as measles and rubella, patients' sera were negative for antibodies to both viruses, but clearly seroconverted to HHV-6 and HHV-7 with $20.0 \%$ and $8.0 \%$, respectively.

In this study we report the occurrence of exanthematous illnesses (most of which clinically diagnosed as E.S) associated with primary HHV-7 infection in Belém, Pará, north Brazil.

\section{MATERIAL AND METHODS}

The study was conducted in Belém, Pará, Brazil between January 1996 and December 2002. A total of 370 blood samples were collected from individuals presenting with exanthematous illnesses at the Virology 
Section of Instituto Evandro Chagas. These patients were selected from an overall 2,550 individuals with exanthematous illnesses (high fever and maculopapular skin rash) who tested negative for the following agents: measles, rubella, Epstein-Barr virus, cytomegalovirus, parvovirus B 19, human herpesvirus-6 (HHV-6) and arboviruses (Mayaro, Oropouche and dengue). Of the 370 individuals 181 were female and 189 were male, with ages ranging from 3 months to 68 years (mean age, 6 years). Blood samples were collected during acute phase of disease by antecubital venepuncture. All sera were stored frozen at $-20{ }^{\circ} \mathrm{C}$ until processed anonimously.

Detection of IgM- and- IgG antibodies to HHV-7 was made using a commercially available immunofluorescence assay (IFA) manufactured by STELLAR BIOSYSTEMSTM (Columbia, USA). This system includes solid-phase multiple-spot slides coated with human lymphocytes infected with HHV-7, as previously described ${ }^{36}$. Sera were tested at a (single) dilution of 1:10 with previous removal of $\mathrm{IgG}$ fraction using GullSORB $^{\mathrm{TM}}$, Salt Lake City, Utah, USA. This ensures that no interference will occur with rheumatoid factor. Tested samples were regarded as HHV-7-IgM positive when a bright green fluorescent staining could be noted in the infected cells of the screening dilution. The presence of HHV-7 IgM antibody in the samples defined recent infection (the cutoff values for negative and positive results for HHV-7 in sera were less than 1:10 and 1:10, respectively).

A subgroup $(n=131)$ of subjects with $\operatorname{IgM}$ and/or high $(>1: 160)$ IgG antibodies level to HHV-7 were selected for DNA detection using the polymerase chain reaction (PCR). This reaction was performed in two steps, essentially as reported before ${ }^{18,37}$. A first amplification was done using a mixture of external oligonucleotide primers (MK1 and MK2), followed by a second amplification (nested PCR) that involved a mixture of the internal primers MK3 and MK4. Each PCR reaction was composed of a mixture including $1.5 \mathrm{mM} \mathrm{MgCl}, 0.5 \mu \mathrm{M}$ of each primer, and 2.5 units of Taq DNA polymerase (INVITROGENTM) in the final concentration. Thermal cycles were ran as follows: 1 initial cycle at $95^{\circ} \mathrm{C}$ for six min, 40 cycles of denaturation at $94^{\circ} \mathrm{C}$ for thirty seconds, annealing at $50{ }^{\circ} \mathrm{C}$ for thirty seconds, and extension at $72{ }^{\circ} \mathrm{C}$ for thirty seconds. A single final extension step at $72{ }^{\circ} \mathrm{C}$ for ten minutes was developed. HHV-7 active infection was defined as the presence of either IgM or IgG antibodies plus the detection of viral DNA. Concurrently, serological assays were used for the detection of both $\operatorname{IgM}$ and $\mathrm{IgG}$ antibodies to rubella, measles, Epstein-Barr virus, cytomegalovirus, parvovirus B19 and HHV-6 ${ }^{10,12,19,22,26,27}$. Serum specimens were also assayed by conventional haemagglutination-inhibition (HI), as described before $^{29}$, for the detection of antibodies to Mayaro, Oropouche and dengue viruses.

Statistical analysis was done with EPI-INFO software, version 6.0 (Atlanta, GA, USA). Comparison of rates between groups was made with the Mantel-Haenszel chi-square test of association or, if assumptions required for the chi-square test were not met, with Fisher's exact test. Siqnificance was defined as $\mathrm{p}<0.05$.

\section{RESULTS}

A total of 190 (51.4\%) of the 370 patients had HHV-7-specific IgM and/or IgG antibodies in their sera, whilst 180 (48.6\%) subjects were found to be IgM- and- IgG seronegative (Table 1). Similar rates of HHV-

7 antibodies (IgM and/or IgG) were noted for female and male subjects: $52.5 \%$ and $50.4 \%$, respectively. Serological status as defined by the presence of HHV-7 IgG antibodies was identified in 135 (36.5\%) patients. In addition, $55(14.9 \%)$ of the 370 patients were found to be HHV-7 IgM- positive. Positivity rates for both female and male subjects were compared [14.4\% versus $15.3 \%$ (IgM+ subgroup) and $35.0 \%$ versus $38.1 \%$ (IgG+ subgroup)], but no significant differences $(\mathrm{p}>0.05)$ were observed. A significant difference $(\mathrm{p}=0.003)$ was seen when female and male IgM-positive subjects aged 5 to 8 months are compared. Prevalence rates ranging from $4.6 \%$ (female, 5-8 months of age) to $93.3 \%$ (female, $>10$ years of age) and $12.2 \%$ (male, $5-8$ months of age) to $80.0 \%$ (male, 8-10) were noted in the IgG-positive subgroups. The prevalence rates increased across the 5 age-groups, if considered the IgM-positive and IgG-positive subjects. The frequency of the recent/active HHV-7 infection was of $11.0 \%(6 / 55)$ among patients whose sera presented levels of IgM-specific antibodies plus DNA detection (Table 1). Of these, four subjects aged less than 1 year and two with 3 and 6 years presented typical E.S. Figure 1 illustrates the nested-PCR displaying the amplified HHV-7 DNA fragments and controls. This analysis included a negative control (lane 1), a positive control (lane 2) and 5 serum samples shown to be DNA-positive (lanes 3-7). No positive results were obtained from

Table 1

Detection of antibodies to HHV-7 in patients with exanthematous illness. Belém, Brazil, 1996-2002

\begin{tabular}{|c|c|c|c|c|c|}
\hline \multirow[b]{2}{*}{ Age } & \multirow[b]{2}{*}{ Sex } & \multicolumn{4}{|c|}{ Serological status, n (\%) } \\
\hline & & $\begin{array}{l}\text { Total }^{*} \\
\text { tested }\end{array}$ & $\operatorname{IgM}+$ & $\mathrm{IgG}+$ & IgM-/IgG- \\
\hline \multicolumn{6}{|l|}{ Months } \\
\hline \multirow[t]{2}{*}{$\leq 4$} & $\mathrm{~F}$ & 21 & $2(9.5)$ & $5(23.8)$ & $14(66.7)$ \\
\hline & M & 16 & $3(18.7)$ & $5(31.2)$ & $8(50.0)$ \\
\hline \multirow[t]{2}{*}{$5-8$} & $\mathrm{~F}$ & $43^{(1)}$ & $11(25.6)^{\mathrm{a}}$ & $2(4.6)$ & $30(69.8)$ \\
\hline & M & 49 & $2(4.1)^{\mathrm{b}}$ & $6(12.2)$ & $41(83.7)$ \\
\hline \multirow[t]{2}{*}{$9-12$} & $\mathrm{~F}$ & $55^{(2)}$ & $9(16.4)$ & $19(34.5)$ & $27(49.1)$ \\
\hline & M & $55^{(1)}$ & $8(14.5)$ & $12(21.8)$ & $35(63.7)$ \\
\hline \multicolumn{6}{|l|}{ Years } \\
\hline \multirow{2}{*}{ 2-4 } & $\mathrm{F}$ & $24^{(1)}$ & $1(4.2)$ & $12(50.0)$ & $11(45.8)$ \\
\hline & M & 31 & $6(19.4)$ & $17(54.8)$ & $8(25.8)$ \\
\hline \multirow{2}{*}{$5-7$} & $\mathrm{~F}$ & 15 & $3(20.0)$ & $11(73.3)$ & $1(6.7)$ \\
\hline & M & $17^{(1)}$ & $6(35.3)$ & $10(58.8)$ & $1(5.9)$ \\
\hline \multirow[t]{2}{*}{$8-10$} & $\mathrm{~F}$ & 8 & $0(0)$ & $6(75.0)$ & $2(25.0)$ \\
\hline & M & 5 & $1(20.0)$ & $4(80.0)$ & $0(0)$ \\
\hline \multirow[t]{2}{*}{$>10$} & $\mathrm{~F}$ & 15 & $0(0)$ & $14(93.3)$ & $1(6.7)$ \\
\hline & M & 16 & $3(18.7)$ & $12(75.0)$ & $1(6.3)$ \\
\hline \multirow[t]{2}{*}{ Subtotal } & $\mathrm{F}$ & 181 & $26(14.4)$ & $69(38.1)$ & $86(47.5)$ \\
\hline & M & 189 & $29(15.3)$ & $66(35.0)$ & $94(49.7)$ \\
\hline Total & & 370 & $55(14.9)^{\mathrm{c}}$ & $135(36.5)^{d}$ & $180(48.6)$ \\
\hline
\end{tabular}




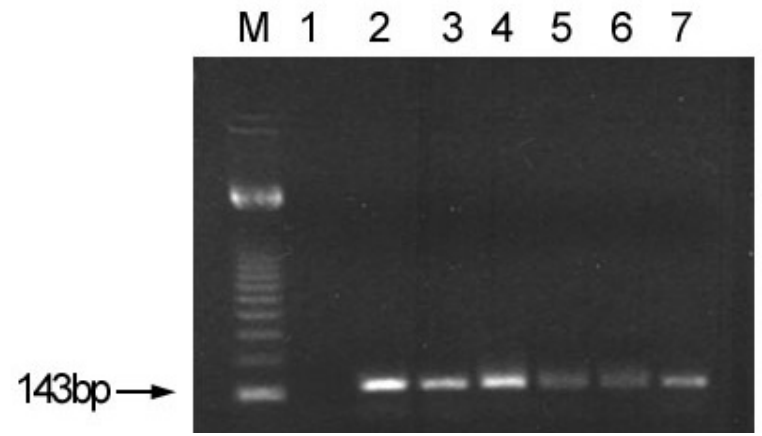

Fig. 1 - Agarose gel electrophoresis of nested PCR- amplified HHV-7 DNA of 7 serum samples, stained with ethidium bromide and photographed under U.V light. Lane 1, negative control; lane 2, HHV-7 control; lanes 3-7, displays HHV-7 positive sera; M denotes molecularweight.

testing sera for potential pathogens other than HHV-7 - including HHV6 - that might be involved in etiology of the exanthematous illness.

\section{DISCUSSION}

Serological studies conducted in both temperate and tropical countries have shown the wide distribution of HHV-7 infection, as well as its association with cases of E.S, mainly in children above 3 years of age and young adults ${ }^{1,3,8,9,11,17,31,34,38}$. Investigations conducted in USA ${ }^{11,38}$ and Mexico $^{21}$ presented rates of $85.0 \%$ and $98.0 \%$, respectively, which are higher than those found in our serosurvey (51.6\%). Conversely, in Japan ${ }^{41}$ lower prevalence rates, $45.0 \%$ and $40.0 \%$ for subjects of $1-4$ and $7-8$ years of age, respectively, were observed. These data suggest that a variation in seroprevalence rates may occur in the different geographical areas. It is likely that methods of sample collection ${ }^{32}$, together with some differences in the techniques ${ }^{41}$ used for the diagnosis of the HHV-7 infection may have accounted for such variable results.

It is noteworthy in our study that a decline in the seroprevalence rates for HHV-7 antibodies occurred among individuals of $\leq 4$ months and 5-8 months if we consider the IgM-positive and IgG-positive. This trend for a gradual decline in antibody levels may reflect the progressive loss of the maternal antibodies ${ }^{11,41}$. This situation was not observed in several other studies including one in $\mathrm{USA}^{11,38}$ that recorded such occurrences in children aged above 3 years, after they had developed primary HHV-6 infections ${ }^{7,8,11}$. In accordance with previous studies ${ }^{11,31}$, this might be related to the persistence of protecting HHV-7 maternal antibodies for longer than HHV-6 antibodies. This fact may explain the occurrence of two primary HHV-7 infections among children aged 3 and 6 years in the present study. In spite of the four recent/active HHV7 infections observed in children with less of one year in our investigation, $49.0 \%$ to $64.0 \%$ of the individuals among $9-12$ months, and $26.0 \%$ to $46.0 \%$ among $2-4$ years examined, were still seronegative for the HHV7. In support to these findings we observed that prevalence rates increased sharply as from two years of age onwards, being of $58.0 \%$ to $75.0 \%$ in age $5-7$ years and $75.0 \%$ to $93.0 \%$ in $>10$ years of age if included those subjects who were IgG-positive only. Analysis of these data leads us to postulate that an epidemiological profile similar to ours was observed mainly in USA and Japan, where primary HHV-7 infections appear to occur later than that by HHV- $6^{8,38}$, therefore being regarded as the second exanthematous illness during childhood ${ }^{32}$.

In this study the frequency of primary HHV-7 infection associated with E.S was similar to that reported for $\mathrm{Japan}^{17}$, around $10.0 \%$. Our results showed that HHV-7 DNA detection in blood (serum) was lower than those reported from other studies that used either saliva ${ }^{5,16}$ or peripheral blood mononuclear cells ${ }^{13,37}$. It is worth to point out that saliva and peripheral blood mononuclear cells are associated with sites of persistence to the HHV-7 $7^{8,30,37}$, where a high virus DNA concentration is expected. It is also worth underscoring the fact that detection of HHV-7 DNA in serum and plasma obtained during acute phase of disease is a marker of primary infection ${ }^{28,36}$.

In our study the patients with primary HHV-7 infections presented with clinical features resembling those of E.S, in general characterized as clinically moderate. Symptoms included high fever and subsequent maculopapular skin rash lasting 24 to 72 hours. Of note, such a typical E.S is often associated with primary HHV-6 infections ${ }^{40}$ and, less frequently, with HHV-7 infection. Severe neurological complications due to invasion of the central nervous system, mainly those associated with E.S, as demonstrated by other authors ${ }^{23,25,33,35}$, were not recorded in the present study.

Our results suggest that HHV-7 infection should be sought in cases of exanthematous illnesses affecting both children and adults in our region and elsewhere. The fact that pathogens other that HHV-7 (including some arboviruses) were ruled out as a likely cause for the exanthematous diseases among our patients sustains our proposed causal relationship between HHV-7 and E.S in our region. To our knowledge, these are the first findings in North Brazil that provide evidence in support to the role that HHV-7 might have as a cause of exanthematous illnesses during childhood.

\section{RESUMO}

\section{Herpesvírus humano-7 como causa de doença exantemática em Belém, Pará, Brasil}

Examinamos soros de 370 pacientes acometidos de doença exantemática, selecionados em Belém, norte do Brasil, com o propósito de se detectarem anticorpos IgM e IgG para o herpesvírus humano-7 (HHV-7). As amostras foram obtidas entre janeiro de 1996 e dezembro de 2002 e, posteriormente, processadas utilizando-se a técnica da imunofluorescência indireta (IFI). Taxas de anticorpos IgM e/ou IgG foram encontradas em 190 (51,4\%) desses pacientes. Observamos taxas de prevalência similares para os sexos feminino e masculino com: 52,5\% e $50,3 \%$, respectivamente. O "status" sorológico foi definido pela presença de anticorpos IgG nos espécimes de 135 (36,5\%) pacientes. A par disso, em 55 (14,9\%) dos 370 pacientes foram detectados anticorpos IgM para o HHV-7. Taxas de anticorpos IgM e IgG para o HHV-7 foram similares $(\mathrm{p}>0.05)$ quando comparamos indivíduos do sexo feminino e masculino: $14,4 \%$ versus $15,3 \%$ e $38,1 \%$ versus $35,0 \%$, respectivamente. Diferença estatisticamente significativa $(\mathrm{p}=0,003)$ foi observada quando comparamos as taxas de anticorpos IgM para o HHV-7 nos indivíduos do grupo etário de 5-8 meses pertencentes ao sexo feminino e masculino. Taxas de prevalência variando de 4,6\% (masculino, 5-8 meses de idade) a $93,3 \%$ (feminino, > 10 anos de idade) e 12,2\% (masculino, 5-8 meses 
de idade) a 80,0\% (masculino, 8-10 anos de idade) foram observadas no subgrupo positivo para IgG. Um subgrupo $(n=131)$ de pacientes com anticorpos IgM ou IgG foi examinado quanto a presença de DNA para o HHV-7 pela técnica da reação em cadeia da polimerase/ "nested" PCR. Infecção recente/ativa para o HHV-7 ocorreu em 11,0\% (6/55) dos pacientes cujas amostras apresentaram anticorpos IgM específicos para o HHV-7. Em um subgrupo $(n=76)$ de pacientes com altos níveis de anticorpos IgG para o HHV-7 (título > 1: 160) não foi detectada a presença de DNA em seus soros pelo PCR/ "nested" PCR. Entre as seis infecções recentes/ativas, quatro indivíduos com menos de um ano e dois com 3 e 6 anos de idade apresentaram típico exantema súbito (E.S) definido por febre elevada $\left(>38,0^{\circ} \mathrm{C}\right)$ com duração de 24 a 72 horas, acompanhandose de erupção cutânea maculopapular.

Nossos resultados ressaltam a necessidade de procurarmos a infecção pelo HHV-7 em pacientes portadores de doença exantemática, particularmente naquelas apresentações típicas de E.S. O HHV-7 parece emergir como um novo patógeno associado a quadros exantemáticos em nossa região.

\section{ACKNOWLEDGMENTS}

We thank Dr. Elisabeth Santos and Talita Monteiro for carrying out the serological tests for rubella, measles and Epstein-Barr virus infections. We are grateful to Dr. Pedro Vasconcelos for performing the serological tests for Mayaro, Oropouche and dengue viruses.

\section{REFERENCES}

1. ASANO, Y.; SUGA, S.; YOSHIKAWA, T.; YAZAKI, T. \& UCHIKAWA, T. - Clinical features and viral excretion in an infant with primary human herpesvirus 7 infection. Pediatrics, 95: 187-190, 1995.

2. BERNEMAN,Z.N.; ABLASHI, D.V.; EGER-FLETCHER, M. et al. - Human herpesvirus7 is a T-lymphotropic virus and is related to, but significantly different from, human herpesvirus-6 and human cytomegalovirus. Proc. nat. Acad. Sci. (Wash.), 89: 1055210556, 1992.

3. BLACK, J.B. \& PELLETT, P.E.- Human herpesvirus 7. Rev. med. Virol., 9: 245-262, 1999.

4. BLACK, J.B.; DURIGON, E.; KITE-POWELL, K. et al. - Seroconversion to human herpesvirus 6 and human herpesvirus 7 among Brazilian children with clinical diagnoses of measles or rubella. Clin. infect. Dis., 23: 1156-1158, 1996.

5. BLACK, J.B.; INOUE, N.; KITE-POWELL, K.; ZAKI, S. \& PELLETT, P.E. - Frequent isolation of human herpesvirus 7 from saliva. Virus Res., 29: 91-98, 1993.

6. BLACK, J.B.; SCHWARZ, T.F.; PATTON, J.L. et al. - Evaluation of immunoassays for detection of antibodies to human herpesvirus-7. Clin. diagn. Lab. Immunol., 3: 7983, 1996.

7. BRIGGS, M.; FOX, J. \& TEDDER, R.S. - Age prevalence of antibody to human herpesvirus 6. Lancet, 1: 1058-1059, 1988.

8. CASERTA, M.T.; HALL, C.B.; SCHNABEL, K.; LONG, C.E. \& D'HERON, N. - Primary human herpesvirus 7 infection: a comparison of human herpesvirus 7 and human herpesvirus 6 infections in children. J. Pediat., 133: 386-389, 1998.

9. CHAN, P.K.; PEIRIS, J.S.; YUEN, K.Y. et al. - Human herpesvirus 6 and human herpesvirus 7 infections in bone marrow transplant recipients. J. med. Virol., 53: 295-305, 1997.
10. CHERNESKY, M.A.; WYMAN, L.; MAHONY, J.B. et al. - Clinical evaluation of the sensitivity and specificity of a commercially available enzyme immunoassay for detection of rubella virus-specific immunoglobulin M. J. clin. Microbiol., 20: 400404, 1984.

11. CLARK, D.A.; FREELAND, J.M.L.; MACKIE, P.L.K.; JARRETT, R.F. \& ONIONS D.E. - Prevalence of antibody to human herpesvirus 7 by age. J. infect. Dis., 168 251-252, 1993.

12. DEBYSER, Z.; REYNDERS, M.; GOUBAU, P. \& DESMYTE, J. - Comparative evaluation of three ELISA techniques and indirect immunofluorescence assay for the serological diagnosis of Epstein-Barr virus infection. Clin. diagn. Virol., 8: 7181, 1997.

13. DI LUCA, D.; ZORZENON, M.; MIRANDOLA, P. et al. - Human herpesvirus 6 and human herpesvirus 7 in chronic fatigue syndrome. J. clin. Microbiol., 33: 1660$1661,1995$.

14. DRAGO, F.; RANIERI, E.; MALAGUTI, F. et al. - Human herpesvirus 7 in patients with pityriasis rosea. Electron microscopy investigations and polymerase chain reaction in mononuclear cells, plasma and skin. Dermatology, 195: 374-378, 1997.

15. FRENKEL, N.; SCHIRMER, E.C.; WYATT, L.S. et al. - Isolation of a new herpesvirus from human CD4+ T cells. Proc. nat. Acad. Sci. (Wash.), 87: 748-752, 1990.

16. HIDAKA, Y.; LIU, Y.; YAMAMOTO, M. et al. - Frequent isolation of human herpesvirus 7 from saliva samples. J. med. Virol., 40: 343-346, 1993.

17. HIDAKA, Y.; OKADA, K.; KUSUHARA, K. et al. - Exanthem subitum and human herpesvirus 7 infection. Pediat. infect. Dis. J., 13: 1010-1011, 1994.

18. KIDD, I.M.; CLARK, D.A.; AIT-KHALED, M.; GRIFFITHS, P.D. \& EMERY, V.C. Measurement of human herpesvirus 7 load in peripheral blood and saliva of healthy subjects by quantitative polymerase chain reaction. J. infect. Dis., 174: 396-401, 1996.

19. LAZZAROTTO, T.; DALlA CASA, B.; CAMPISI, B. \& LANDINI, M.P. - Enzyme linked immunoadsorbent assay for the detection of cytomegalovirus -IgM: comparison between eight commercial kits, immunofluorescence, and immunoblotting. J. clin. Lab. Anal., 6: 216-218, 1992.

20. LUSSO, P.; SECCHIERO, P.; CROWLEY, R.W. et al. - CD4 is a critical component of the receptor for human herpesvirus 7: interference with human immunodeficiency virus. Proc. nat. Acad. Sci. (Wash.), 91: 3872-3876, 1994.

21. MEDINA, J.R.; KRUEGER, G.R.F.; BONIFAZ GRACIAS, R.; BERNEMAN, Z. \& $\mathrm{KOCH}, \mathrm{B}$. - Prevalencia del virus humano herpes 7 en donadores de sangre mexicanos. Rev. Invest. clin., 47: 467-471, 1995.

22. PARKER, C.A. \& WEBER, J.M. - An enzyme-linked immunosorbent assay for the detection of IgG and IgM antibodies to human herpesvirus type 6. J. virol. Meth., 41: $265-275,1993$

23. POHL-KOPPE, A.; BLAY, M.; JÄGER, G. \& WEISS, M. - Human herpesvirus type 7 DNA in the cerebrospinal fluid of children with central nervous system diseases. Europ. J. Pediat., 160: 351-358, 2001.

24. PORTOLANI, M.; CERMELLI, C.; MIRANDOLA, P. \& DI LUCA, D. - Isolation of human herpesvirus 7 from an infant with febrile syndrome. J. med. Virol., 45: 282$283,1995$.

25. PORTOLANI, M.; LEONI, S.; GUERRA, A. et al. - Human herpesvirus- 7 DNA in cerebrospinal fluid. Minerva Pediat., 50: 39-44, 1998.

26. ROSSIER, E.; MILlER, H.; McCULlOCH, B.; SUlLIVAN, L. \& WARD, K. Comparison of immunofluorescence and enzyme immunoassay for detection of measles-specific immunoglobulin M antibody. J. clin. Microbiol., 29: 1069-1071, 1991. 
27. SALIMANS, M.M.; VAN BUSSEL, M.J.; BROWN, C.S. \& SPAAN, W.J. - Recombinant parvovirus B19 capsids as a new substrate for detection of B19 - specific IgG and IgM antibodies by an enzyme - linked immunosorbent assay. J. virol. Meth., 39: 247-258, 1992.

28. SECCHIERO, P.; CARRIGAN, D.R.; ASANO, Y. et al. - Detection of human herpesvirus 6 in plasma of children with primary infection and immunosuppressed patients by polymerase chain reaction. J. infect. Dis., 171: 273-280,1995.

29. SHOPE, R.E. - The use of a microhemagglutination - inhibition test to follow antibody response after arthropod - borne virus infection in a community of forest animals. An. Microbiol. (Rio de J.), 11: 167-171, 1963.

30. TAKAHASHI, Y.; YAMADA, M.; NAKAMURA, J. et al. - Transmission of human herpesvirus 7 through multigenerational families in the same household. Pediat. infect. Dis., 16: 975-978, 1997.

31. TANAKA, K.; KONDO, T.; TORIGOE, S. et al. - Human herpesvirus 7: another causal agent for roseola (exanthem subitum). J. Pediat., 125: 1-5, 1994.

32. TANAKA-TAYA, K.; KONDO, T.; MUKAI, T. et al. - Seroepidemiological study of human hespesvirus- 6 and -7 in children of different ages and detection of these two viruses in throat swabs by polymerase chain reaction. J. med. Virol., 48: 88-94, 1996

33. TORIGOE, S.; KOIDE, W.; YAMADA, M. et al. - Human herpesvirus 7 infection associated with central nervous system manifestations. J. Pediat., 129: 301-305, 1996.

34. TORIGOE, S.; KUMAMOTO, T.; KOIDE, W.; TAYA, K. \& YAMANISHI, K. - Clinical manifestation associated with human herpesvirus 7 infection. Arch. Dis. Child., 72: 518-519, 1995.
35. VAN DEN BERG, J.S.; VAN ZEIJL, J.H.; ROTTEVEEL, J.J. et al. - Neuroinvasion by human herpesvirus type 7 in a case of exanthem subitum with severe neurologic manifestations. Neurology, 52: 1077-1079, 1999.

36. WARD, K.N.; COUTO PARADA, X.; PASSAS, J. \& THIRUCHELVAN, A.D. Evaluation of the specificity and sensitivity of indirect immunofluorescence tests for IgG to human herpesvirus-6 and -7. J. virol. Meth., 106: 107-113, 2002.

37. WILBORN, F.; SCHMIDT, C.A.; LORENZ, F. et al. - Human herpesvirus type 7 in blood donors: detection by the polymerase chain reaction. J. med. Virol., 47: 65-69, 1995

38. WYATT, L.S. \& FRENKEL, N. - Human herpesvirus 7 is a constitutive inhabitant of adult human saliva. J. Virol., 66: 3206-3209, 1992.

39. WYATT, L.S.; RODRIGUEZ, W.J.; BALACHANDRAN, N. \& FRENKEL, N. - Human herpesvirus-7: antigenic properties and prevalence in children and adults. J. Virol., 65: 6260-6265, 1991.

40. YAMANISHI, K.; OKUNO, T.; SHIRAKI, K. et al. - Identification of human herpesvirus6 as a causal agent for exanthem subitum. Lancet, 1: 1065-1067, 1988.

41. YOSHIKAWA, T.; ASANO, Y.; KOBAYASHI, I. et al. - Seroepidemiology of human herpesvirus 7 in healthy children and adults in Japan. J. med. Virol., 41: 319-323, 1993

42. YOSHIKAWA, T.; IHIRA, M.; SUZURI, K. et al. - Invasion by human herpesvirus 6 and human herpesvirus 7 of the central nervous system in patients with neurological signs and symptoms. Arch. Dis. Child., 83: 170-171, 2000.

Received: 9 February 2004

Accepted: 31 May 2004 